\section{Ethephon Residual Catalysis on Unrooted Impatiens hawkeri Cuttings and Stock Plants}

\author{
W. Roland Leatherwood ${ }^{1}$ \\ Cornell University, Department of Horticulture, 134A Plant Science \\ Building, Ithaca, NY 14853
}

John M. Dole

North Carolina State University, Department of Horticultural Science, Campus Box 7609, Kilgore 227A, Raleigh, NC 27695

\section{James E. Faust \\ Clemson University, Department of Horticulture, E-143 Poole Agricultural Center, Clemson, SC 29634}

Additional index words. ethylene, postharvest, storage

\begin{abstract}
Ethephon [(2-chloroethyl) phosphonic acid] is used to increase stock plant cutting productivity through increased flower and flower bud abscission and branching. However, ethylene evolution resulting from ethephon application is suspected to cause leaf abscission of unrooted cuttings during shipping. It was the objective of this study to assess ethylene evolution from ethephon-treated cuttings during storage and shipping of unrooted cuttings. Impatiens hawkeri W. Bull 'Sonic Red' and 'Sonic White' stock plants were treated with $0,250,500$, or $1000 \mathrm{mg} \cdot \mathrm{L}^{-1}$ ethephon. Cuttings were harvested from 1 to 21 days later and each harvest was stored at $20^{\circ} \mathrm{C}$ in sealed jars for $24 \mathrm{~h}$ before ethylene measurement. Higher ethephon doses resulted in greater ethylene generation. Cuttings harvested 1 day after treatment with $0,250,500$, or $1000 \mathrm{mg} \cdot \mathrm{L}^{-1}$ ethephon evolved 0.07 , 1.3, 1.7, or $5.8 \mu \mathrm{L} \cdot \mathrm{L}^{-1} \cdot \mathrm{g}^{-1}$ (fresh weight) ethylene in the first $24 \mathrm{~h}$ of storage at $20{ }^{\circ} \mathrm{C}$, respectively. Twenty-one days after treatment, cuttings from the same plants evolved $0.05,0.05,0.15$, or $0.14 \mu \mathrm{L} \cdot \mathrm{L}^{-1} \cdot \mathrm{g}^{-1}$ (fresh weight) ethylene in the first $24 \mathrm{~h}$ of storage at $20{ }^{\circ} \mathrm{C}$, respectively. As cuttings were harvested from Day 1 to Day 21, ethylene concentrations evolved within the first $24 \mathrm{~h}$ of storage decreased exponentially. Rinsing cuttings, treated $24 \mathrm{~h}$ earlier with $500 \mathrm{mg} \cdot \mathrm{L}^{-1}$ ethephon, by gently agitating for $10 \mathrm{~s}$ in deionized water reduced ethylene evolution to $0.7 \mu \mathrm{L} \cdot \mathrm{L}^{-1} \cdot \mathrm{g}^{-1}$ (fresh weight) as compared with 1.7 for unrinsed cuttings. Cuttings harvested $24 \mathrm{~h}$ after treatment with $500 \mathrm{mg} \cdot \mathrm{L}^{-1}$ ethephon stored at $10,15,20$, and $25^{\circ} \mathrm{C}$ for $24 \mathrm{~h}$ evolved $0.37,0.81,2.03$, and $3.55 \mu \mathrm{L} \cdot \mathrm{L}^{-1} \cdot \mathrm{g}^{-1}$ (fresh weight) ethylene. The resulting mean temperature coefficient $\left(Q_{10}\right)$ for the 10 to $25{ }^{\circ} \mathrm{C}$ range from all replications was $5.15 \pm \mathbf{0 . 8 5}$. Thus, ethylene continues to evolve from ethephon-treated Impatiens hawkeri stock plants for up to 21 days and can accumulate to high concentrations during cutting storage.
\end{abstract}

Ornamental plant producers use cuttings shipped from around the world for finished plant production. The value of unrooted cutting imports into the United States totaled $\approx \$ 61$ million in 2006 with the bulk coming from Central America, South America, Mexico, and Asia (Foreign Agricultural Service, 2007). In the top 15 floricultural crop-producing states, flats, hanging baskets, and pots of geraniums (Pelargonium L'Hér. ex Ait.), poinsettias (Euphorbia pulcherrima Willd. ex Klotzsch), and New Guinea impatiens (Impatiens haw-

Received for publication 14 Aug. 2008. Accepted for publication 27 Jan. 2009.

We thank Dr. Erik Runkle of Michigan State University for his valuable collaboration. We also thank The American Floral Endowment, Ball Horticultural Company, Paul Ecke Ranch, Fischer USA, and Oro Farms for their support of this work. We also acknowledge the generous gift of cuttings by Fischer USA.

${ }^{1}$ To whom reprint requests should be addressed; e-mailwrl32@cornell.edu. sequent cellulase and polygalacturonase activity (Mishra et al., 2008), thus reducing sink tissue carbohydrate demands. Ethylenerelated inhibition of indole-3-acetic acid (IAA) synthesis (Chadwick and Burg, 1970; Weber and Osborn, 1969) is a likely cause of increased branching in both young liners and stock plants (Faust and Lewis, 2005; Hayashi et al., 2001) treated with ethephon.

Stock plant sink tissue management has been critical in lowering cutting losses resulting from carbohydrate depletion during shipping. Rapaka et al. (2008) demonstrated an inverse relationship between cutting carbohydrate content at harvest and subsequent postharvest leaf senescence. Quality of subsequent rooting is also directly proportional to carbohydrate content (Rapaka et al., 2005). Other authors have suggested a correlation between cut flower petal senescence and sugar depletion (van Doorn, 2004).

Problematically, excess ethylene can damage unrooted cuttings by promoting apical meristem necrosis, leaf yellowing, and abscission. Thus, cuttings harvested from ethephon-treated stock plants still evolving ethylene may be exposed to damaging ethylene concentrations during packaging and shipping. Because ethephon-treated plants do not rapidly replace the abscised sink tissues, it may be possible to postpone cutting harvest after ethephon application until ethylene concentrations return to normal. The objective of this study was to investigate the persistence of residual ethephon activity on stock plants and unrooted cuttings. We applied a range of ethephon concentrations and subsequent storage treatments to show how temperature and rinsing of cuttings may affect ethylene evolution.

\section{Materials and Methods}

Plant material. Five unrooted cuttings of each Impatiens hawkeri W. Bull 'Sonic Red' and 'Sonic White' were propagated into 30 -cm diameter, $13.85-\mathrm{L}$ plastic pots containing a soilless growing substrate (Fafard 3P; Conrad Fafard, Inc., Agawam, MA). Once rooted, these plants were maintained as stock plants and irrigated manually with water alone, $600 \mathrm{mg} \cdot \mathrm{L}^{-1}$ nitrogen liquid fertilizer (20N-4.37P-16.6K; Ultrasol, SQM North America, Atlanta, GA), or flowable lime (Limestone F; Cleary Chemical Inc., Dayton, $\mathrm{NJ})$ to maintain a target electrical conductivity of 1.0 to $1.5 \mathrm{dS} \cdot \mathrm{m}^{-1}$ and a $\mathrm{pH}$ of 5.8 to 6.2 using the pourthrough monitoring method. Temperature set points were $24 / 18{ }^{\circ} \mathrm{C}$ (day/ night), and average daily light integral was $6.1 \mathrm{~mol} \cdot \mathrm{m}^{-2} \cdot \mathrm{d}^{-1}$.

Ethephon application and cutting storage. Ethephon (Florel; Monterey Lawn and Garden Products, Inc., Fresno, CA) treatments were applied at $1600 \mathrm{HR}$ with a 2-L compression hand sprayer (Hudson Manufacturing Company, Chicago, IL) at 0, 250, 500 , or $1000 \mathrm{mg} \cdot \mathrm{L}^{-1}$ a.i. to three plants each. Cuttings were harvested at $0900 \mathrm{HR}$ the next day and every $48 \mathrm{~h}$ thereafter for $21 \mathrm{~d}$ for a total of 11 harvests. Two node cuttings of 


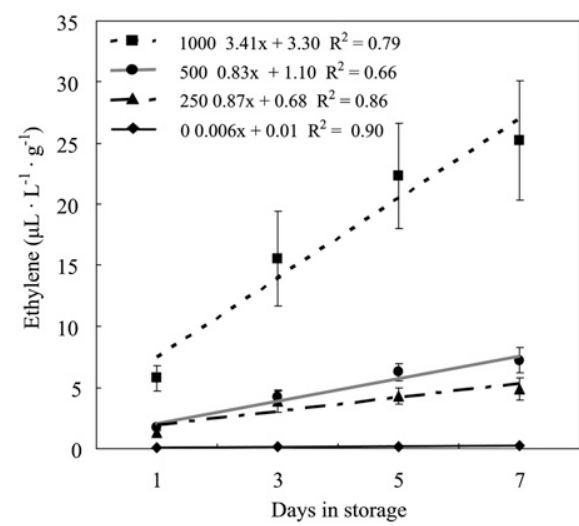

Fig. 1. Cumulative ethylene evolved from unrooted Impatiens 'Sonic Red' and 'Sonic White' cuttings during storage at $20 \pm 1{ }^{\circ} \mathrm{C}$ beginning $24 \mathrm{~h}$ after ethephon application to stock plants. Mean values of three replications $(n=3)$ are presented. Error bars indicate $\pm 1 \mathrm{SE}$.

similar size and age with three to four fully expanded leaves were arbitrarily selected from all parts of the stock plant. Cutting fresh weights were recorded before six each were placed in sealed 0.95-L glass jars. The jars were stored in the dark at $20 \pm 1^{\circ} \mathrm{C}$ for $7 \mathrm{~d}$ and they remained closed for the storage duration. Ethylene concentrations in the jars were measured by gas chromatography every other day beginning $24 \mathrm{~h}$ after each harvest and ethylene evolved from the cuttings was calculated on a fresh weight basis. For the rinsing experiment, an additional group of $500 \mathrm{mg} \cdot \mathrm{L}^{-1}$ ethephon-treated cuttings was gently rinsed for $10 \mathrm{~s}$ in $100 \mathrm{~mL}$ of deionized water and gently blotted dry before storage. For the temperature treatment experiment, four additional sets of $500 \mathrm{mg} \cdot \mathrm{L}^{-1}$ ethephontreated cuttings were harvested $24 \mathrm{~h}$ after treatment and stored at $10,15,20$, or $25^{\circ} \mathrm{C}$, respectively, in sealed $0.95-\mathrm{L}$ glass jars for $7 \mathrm{~d}$.

Ethylene determination and cutting condition. A gas chromatograph (Varian 3400; Varian Inc., Walnut Creek, CA) fitted with a glass column (Porapak Q, 80-100 mesh, $183 \mathrm{~cm} \cdot 2 \mathrm{~mm}$; Sigma Aldrich, Inc., St. Louis, MO) running at $120^{\circ}$ injector, $120^{\circ}$ column, and $130{ }^{\circ} \mathrm{C}$ detector (flame ionization) temperatures was used to measure ethylene concentration during storage. Flow rates for the $\mathrm{He}$ carrier, $\mathrm{H}_{2}$, and $\mathrm{O}_{2}$ were 30,16 , and $90 \mathrm{~mL} / \mathrm{min}$, respectively. Ethylene quantification was based on a response factor generated using a $1 \mu \mathrm{L} \cdot \mathrm{L}^{-1}$ ethylene standard. Injection volume was $1 \mathrm{~mL}$ of headspace gas drawn through a neoprene port on the jar lid.

In addition, evidence of phytotoxicity was recorded daily as the number of yellow or necrotic leaves, the percentage of leaf area affected, the number of abscised leaves, and turgidity, which was ranked on the following scale: $1=$ all leaves turgid; $2=$ one or two leaves wilting; or $3=$ all leaves wilted.

Data analysis. Within the study, each of the three experiments was designed as a randomized complete block design of three blocks with treatments of ethephon concentration, storage temperature, and rinsing of resid-

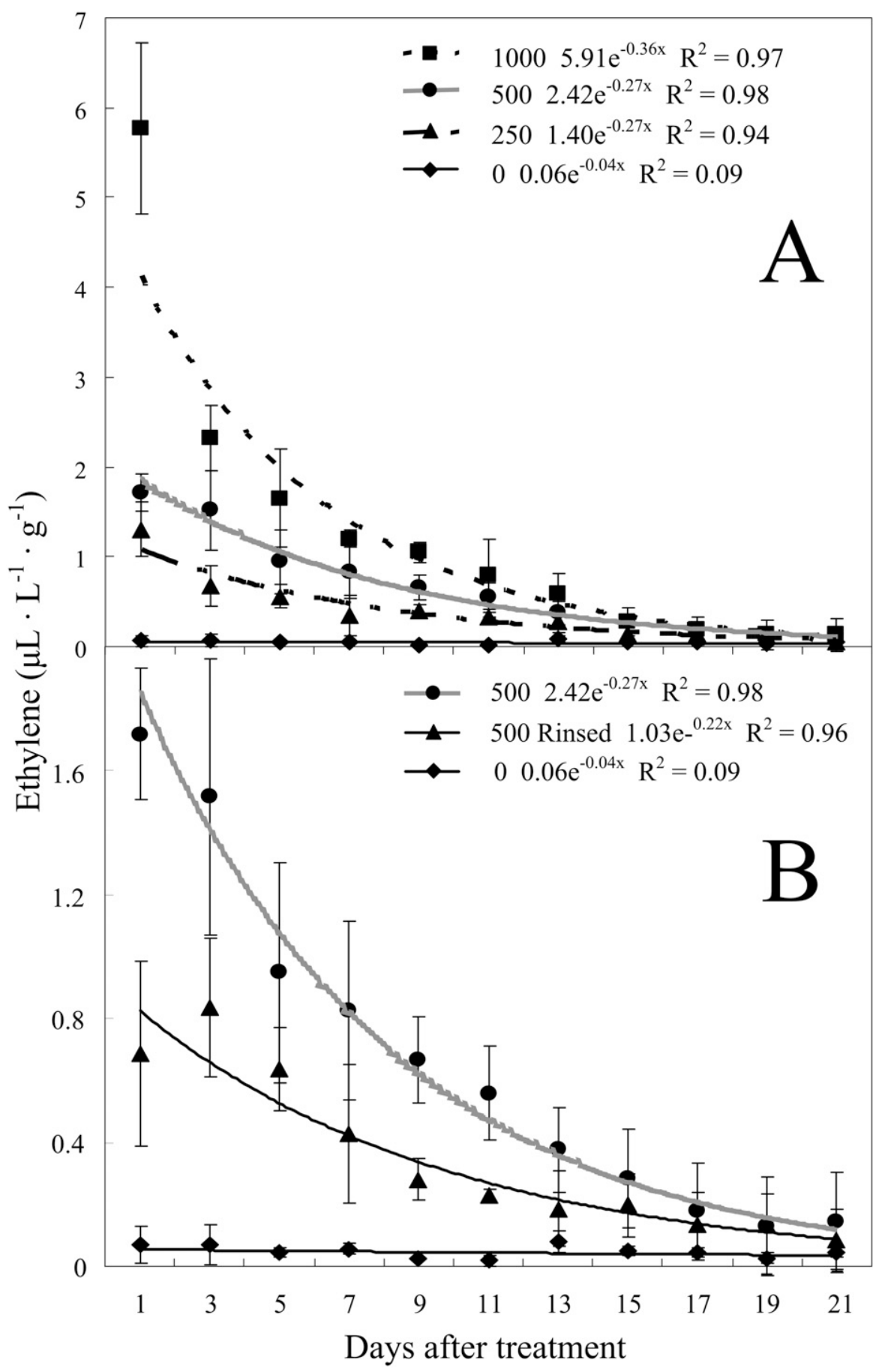

Fig. 2. Ethylene evolved during the first $24 \mathrm{~h}$ after harvest for unrooted Impatiens 'Sonic Red' and 'Sonic White' cuttings harvested every other day 1 to $21 \mathrm{~d}$ after ethephon application to stock plants. Ethylene evolution after $24 \mathrm{~h}$ of storage for a range of ethephon treatment concentrations (A) and rinsed cuttings (B) are shown. Mean values of three replications $(n=3)$ are presented. Error bars indicate $\pm 1 \mathrm{SE}$.

ual ethephon. Experimental results (i.e., ethylene evolved as a result of ethephon dosage, storage temperature, or rinsing) were tested for significance and best fit linear, exponential, quadratic, or higher-order models using the GLM procedure. Model terms were evaluated for significance by comparison of $F$ values at $\alpha=0.05$. Subsequent regression analysis using the best fit model was performed using PROC REG (SAS Institute, Cary, NC). The equation $\left.\left(\mathrm{R}_{2} / \mathrm{R}_{1}\right)^{(10 /(\mathrm{T}} 2-\mathrm{T}_{1}\right)$ was used to calculate $Q_{10}$ values for ethylene evolution during the first $24 \mathrm{~h}$ of storage $1 \mathrm{~d}$ after treatment for temperature ranges 10 to $15^{\circ}, 15$ to $20^{\circ}$, and 20 to $25^{\circ} \mathrm{C}$ in each replication. The resulting data were tested using Scheffe's procedure (PROC GLM) with an experimentwise Type I error rate at $\alpha=0.05$.

\section{Results}

During storage, the quality and appearance of cuttings from all treatments were similar. Additionally, no statistically significant 
differences were observed between cultivars in the initial experiments; thus, cuttings were pooled during subsequent experiments. Higher ethephon doses resulted in greater ethylene generation and ethylene accumulated to very high concentrations (Fig. 1) over the 7-d storage period in all experiments. Cuttings harvested $24 \mathrm{~h}$ after treatment with 500 or $1000 \mathrm{mg} \cdot \mathrm{L}^{-1}$ ethephon produced 1.7 or $5.8 \mu \mathrm{L} \cdot \mathrm{L}^{-1} \cdot \mathrm{g}^{-1}$ ethylene, respectively, within the first $24 \mathrm{~h}$ after harvest. Control cuttings produced $0.06 \mu \mathrm{L} \cdot \mathrm{L}^{-1} \cdot \mathrm{g}^{-1}$ ethylene in the same period. We reported ethylene accumulation within the first $24 \mathrm{~h}$ of storage for the rinsing, residual activity, and temperature experiments to simplify the results presentation and reduce duplication.

Ethylene evolved from ethephon-treated plants for at least an additional $21 \mathrm{~d}$ after treatment depending on application rate (Fig. 2A). Cuttings harvested $1 \mathrm{~d}$ after treatment with $0,250,500$, or $1000 \mathrm{mg} \cdot \mathrm{L}^{-1}$ ethephon produced $0.07,1.3,1.7$, or $5.8 \mu \mathrm{L} \cdot \mathrm{L}^{-1} \cdot \mathrm{g}^{-1}$ ethylene in the first $24 \mathrm{~h}$ of storage, respectively. As subsequent sets of cuttings were harvested, ethylene produced within the first $24 \mathrm{~h}$ of storage decreased exponentially Day 1 through 21. Cuttings harvested $21 \mathrm{~d}$ after being treated by the same ethephon concentrations produced $0.05,0.05,0.15$, or 0.14 $\mu \mathrm{L} \cdot \mathrm{L}^{-1} \cdot \mathrm{g}^{-1}$ ethylene in the first $24 \mathrm{~h}$ of storage, respectively.

Rinsing $500 \mathrm{mg} \cdot \mathrm{L}^{-1}$ ethephon-treated cuttings with water did not reduce evolved ethylene concentrations compared with that of the untreated control in the first $13 \mathrm{~d}$ after treatment (Fig. 2B). Cuttings harvested $24 \mathrm{~h}$ after treatment with $500 \mathrm{mg} \cdot \mathrm{L}^{-1}$ ethephon and rinsed in distilled water produced 0.7 $\mu \mathrm{L} \cdot \mathrm{L}^{-1} \cdot \mathrm{g}^{-1}$ ethylene in the first $24 \mathrm{~h}$ of storage compared with $1.7 \mu \mathrm{L} \cdot \mathrm{L}^{-1} \cdot \mathrm{g}^{-1}$ ethylene from unrinsed cuttings and $0.05 \mu \mathrm{L} \cdot \mathrm{L}^{-1} \cdot \mathrm{g}^{-1}$ for untreated cuttings.

Lower temperatures resulted in significantly less ethylene generation from ethephon-treated cuttings (Fig. 3) within the first $24 \mathrm{~h}$ of storage. Cuttings harvested $24 \mathrm{~h}$ after treatment with $500 \mathrm{mg} \cdot \mathrm{L}^{-1}$ ethephon and stored at $10,15,20$, and $25^{\circ} \mathrm{C}$ evolved 0.37 , $0.85,2.59$, and $3.56 \mu \mathrm{L} \cdot \mathrm{L}^{-1} \cdot \mathrm{g}^{-1}$ of ethylene, respectively. The relationship between storage temperatures and ethylene concentrations evolved within the first $24 \mathrm{~h}$ of storage $1 \mathrm{~d}$ after ethephon application is best described by the linear equation, $0.21 \mathrm{x}-1.97\left(R^{2}=0.88\right)$. Additionally, these cuttings had a highest temperature coefficient $\left(\mathrm{Q}_{10}\right)$ of 10.25 from 15 to $20^{\circ} \mathrm{C}$, and 4.70 and 2.18 from 10 to $15^{\circ} \mathrm{C}$ and 20 to $25^{\circ} \mathrm{C}$, respectively. Although the $\mathrm{Q}_{10}$ for 15 to $20^{\circ} \mathrm{C}$ differed significantly from the $\mathrm{Q}_{10}$ for 10 to $15^{\circ} \mathrm{C}$ and 20 to $25^{\circ} \mathrm{C}$, the latter two did not differ significantly from one another.

\section{Discussion}

Cuttings are typically packaged for shipment in polypropylene or polyethylene bags, which offer only a fraction of the headspace of the $0.95-\mathrm{L}$ jars used in this study. Total shipping and handling times rarely exceed $4 \mathrm{~d}$

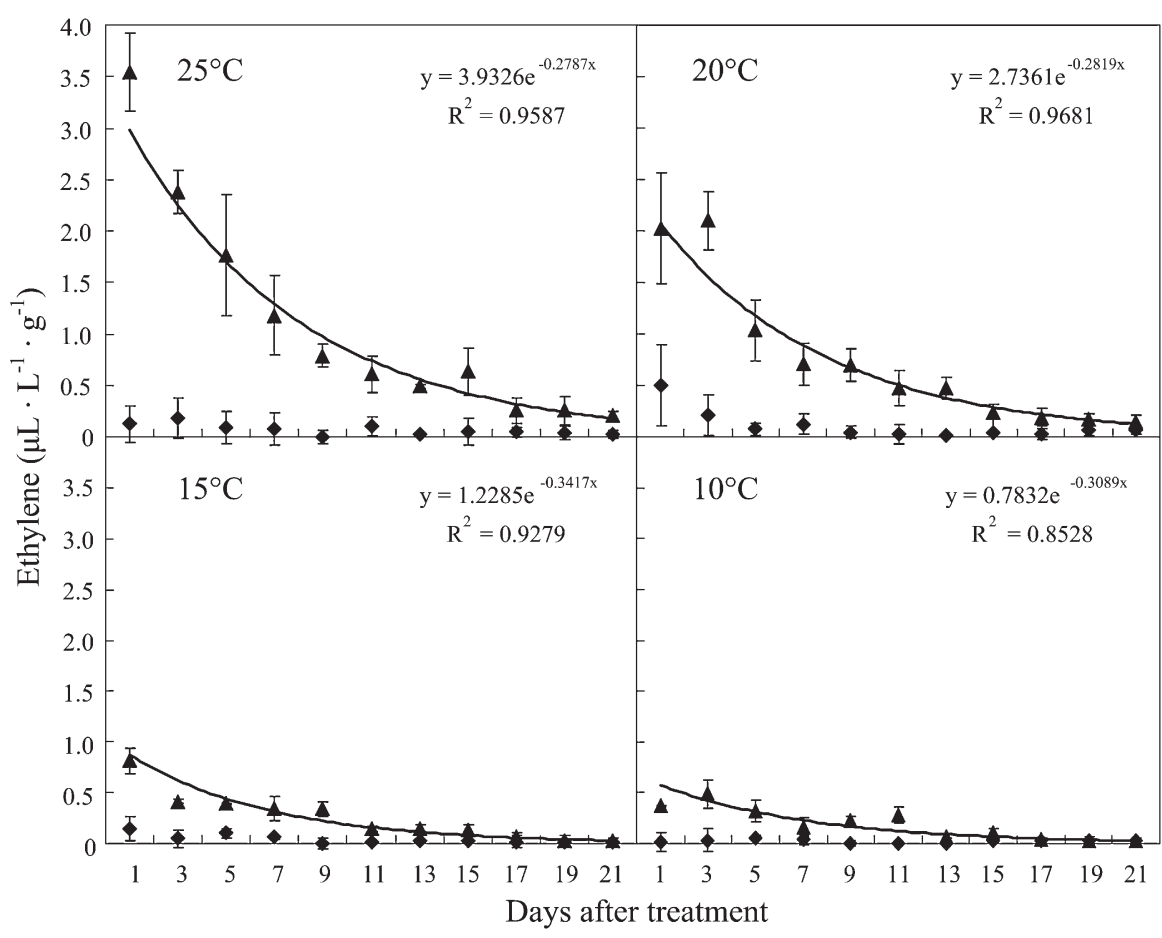

Fig. 3. Ethylene accumulation during the first $24 \mathrm{~h}$ after harvest for unrooted Impatiens 'Sonic Red' and 'Sonic White' cuttings stored at four different temperature conditions. Cuttings were harvested for 1 to $21 \mathrm{~d}$ after $500 \mathrm{mg} \cdot \mathrm{L}^{-1}(\boldsymbol{\Delta})$ and $0 \mathrm{mg} \cdot \mathrm{L}^{-1}(\diamond)$ ethephon application to stock plants. Mean ethylene concentrations from three replications $(n=3)$ are reported as concentration per fresh weight. Error bars indicate $\pm 1 \mathrm{SD}$.

(R. Heins, A. Gerendas, personal communication). Thus, ethylene concentrations in this experiment measured in the first $24 \mathrm{~h}$ of storage may be artificially low. The same number of cuttings placed into a polypropylene shipping bag with very little headspace may evolve ethylene concentrations, which are severely damaging for some species. In shipping, problems may occur when cuttings of ethylene-sensitive species are packed alongside ethephon-treated cuttings. Species susceptible to ethylene concentrations as low as $0.1 \mu \mathrm{L} \cdot \mathrm{L}^{-1}$ such as Lantana camera $\mathrm{L}$. or Portulaca oleracea L. (Leatherwood, 2008; Rapaka et al., 2007) could suffer leaf abscission when packaged alongside cuttings still releasing ethylene. Safe ethylene concentrations for all herbaceous cuttings are not yet known. However, concentrations of 0.01 $\mu \mathrm{L} \cdot \mathrm{L}^{-1}$ for $20 \mathrm{~h}$ can damage the flowers of a number of cut flower species (Blankenship and Dole, 2003). Reports of ethylene damage during shipping such as leaf abscission have been difficult to confirm because ethylene dissipates once the packages are opened. Additional follow-up experiments should examine this headspace issue and combine various cuttings sensitive to ethylene with cuttings recently treated with ethephon.

Our findings support work by Woodrow et al. (1988) with $\left[{ }^{14} \mathrm{C}\right]$ ethephon, who reported that $300 \mathrm{mg} \cdot \mathrm{L}^{-1}$ ethephon degradation on Solanum lycopersicum L. var. cerasiforme (Dunal) Spooner, G.J. Anderson \& R.K. Jansen releases ethylene continually for at least $9 \mathrm{~d}$ after treatment and is not synthesized de novo. Additionally, Riov and Yang (1982) demonstrated that after exposure to exogenous $12 \mu \mathrm{L} \cdot \mathrm{L}^{-1}$ ethylene, ethylene autocatalysis of Citrus sinensis L. Osbeck cv. Washington Navel leaf discs decreases to normal within $12 \mathrm{~h}$ of removing the exogenous ethylene source. Woolf et al. (1995) reported a decrease in ethylene evolution from Camellia saluenesis $\times C$. japonica 'Anticipation' leaves and vegetative buds treated with $4 \mathrm{~mL} \cdot \mathrm{L}^{-1}$ ethephon a.i. (Ethrel 48; Rhone-Poulenc Ltd., Wellington, New Zealand) as temperatures decreased from 30 to $10^{\circ} \mathrm{C}$. Thus, it appears that ethephon can have residual activity on impatiens stock plants for at least 3 weeks, is the primary ethylene source observed in this study, and evolves ethylene more slowly at lower temperatures.

Decreasing ethephon concentration results in lower ethylene concentrations evolved from treated cuttings. Thus, it may be possible to establish a minimal effective dose to improve branching and abscise flowers and flower buds while also reducing ethylene evolved. Although rinsing cuttings treated with $500 \mathrm{mg} \cdot \mathrm{L}^{-1}$ ethephon reduced the amount of ethylene generated from ethephon application, ethylene concentrations were similar to amounts generated by unrinsed cuttings harvested from stock plants treated with $250 \mathrm{mg} \cdot \mathrm{L}^{-1}$ ethephon. Rinsing most likely removes some of ethephon adhered to the cuticle surface but does not remove ethephon embedded in the cuticle. However, rinsing of cuttings or stock plants may not be 
horticulturally feasible considering the costs and disease risks the action would impose.

We have demonstrated that ethephon ethylene evolution decreases over time. By delaying cutting harvests after ethephon application, growers could dramatically decrease the ethylene evolved during shipping. Growers report, however, waiting as little as $2 \mathrm{~d}$ before harvesting after ethephon application (B. Troost, personal communication). Awareness of the ethylene status of unrooted cuttings will help producers and growers manage the cold chain and propagation environment more precisely. Storage temperatures less than $15{ }^{\circ} \mathrm{C}$ reduced $\mathrm{Q}_{10}$ and thus the amount of ethylene generated by treated cuttings within $24 \mathrm{~h}$ of harvest. It is possible that at lower temperatures, ethephon's rate of absorption slows as the cuticle and cell membranes become less permeable. Because ethephon autocatalyzes in the apoplast (Yang, 1969), ethylene synthesizing metabolic activity (Woodrow et al., 1988) can be ruled out. Because ethephon degradation peaks between 15 and $20^{\circ} \mathrm{C}$, storage and handling of cuttings harvested from recently treated stock plants should be conducted at less than $15{ }^{\circ} \mathrm{C}$. Once a cutting shipment leaves the production facility, however, control over temperature is a challenge and peaks of $25{ }^{\circ} \mathrm{C}$ are common. Thus, whenever possible, producers should avoid combined boxes of ethephon-treated cuttings and cuttings of ethylene-sensitive species. If combined shipments cannot be avoided, include in the shipment an ethylene blocker such as 1methylcyclopropene (Blankenship and Dole, 2003).

Regardless of these findings, ethephon alters the carbohydrate distribution in the parent plant through abscission of flowers and flower buds, thus increasing carbohydrate availability to the shoots (Woodrow et al., 1988) and unrooted cutting carbohy- drate content. Cuttings with higher carbohydrate content have improved adventitious root formation (Rapaka et al., 2005) and propagation performance. Thus, ethephon is still a valuable tool in cutting production yet should be used with an awareness of these findings. Further research should look into establishing minimal effective ethephon applications, handling and shipping procedures to minimize ethylene evolution and exposure, and delay of harvesting to allow ethephon dissipation.

\section{Literature Cited}

Blankenship, S.M. and J.M. Dole. 2003. 1-Methylcylopropene; a review. Postharvest Biol. Technol. 28:1-25.

Chadwick, A.V. and S.P. Burg. 1970. Regulation of root growth by auxin-ethylene interaction Plant Physiol. 45:192-200.

Faust, J.E. and K.P. Lewis. 2005. The effects of ethephon on cutting yield of 23 selected annual cultivars. Acta Hort. 683:141-144.

Foreign Agricultural Service. 15 Dec. 2007. U.S trade imports-FAS commodity aggregations. U.S. Department of Agriculture, Washington, DC. 28 Dec. 2007. <http://www.fas.usda.gov/ ustrade/USTImHS10.asp>.

Goren, R., E. Dagan, O. Sagee, J. Riov, and S.F. Yang. 1993. Abscission in citrus leaf explants: Rolfe of ABA-induced ethylene. Acta Hort. 392:43-50.

Hansen, H. and K. Grossmann. 2000. Auxininduced ethylene triggers abscisic acid biosynthesis and growth inhibition. Plant Physiol. 124:1437-1448

Hayashi, T., R.D. Heins, A.C. Cameron, and W.H. Carlson. 2001. Ethephon influences flowering, height, and branching of several herbaceous perennials. Scientia Hort. 91:305-324.

Klee, H.J. 2002. Control of ethylene-mediated process in tomato at the level of receptors. J. Expt. Bot. 53:2057-2063.

Leatherwood, W.R. 2008. Managing the postharvest physiology of unrooted cuttings to enhance shipping and postharvest quality. $\mathrm{PhD}$ diss., $\mathrm{NC}$ State Univ., Raleigh, NC.
Mishra, A., S. Khare, P.K. Trivedi, and P. Nath. 2008. Effect of ethylene, 1-MCP, ABA and IAA on break strength, cellulase and polygalacturonase activities during cotton leaf abscission. S. Afr. J. Bot. 74:282-287.

National Agriculture Statistics Service. 2007. Floriculture crops 2006 summary. US Dept. Agr. 18-72.

Rapaka, V., J. Faust, J. Dole, and E. Runkle. 2008. Endogenous carbohydrate status affects postharvest ethylene sensitivity in relation to leaf senescence and adventitious root formation in Pelargonium cuttings. Postharvest Biol. Technol. 48:272-282.

Rapaka, V.J., B. Bessler, M. Schreiner, and U. Druege. 2005. Interplay between initial carbohydrate availability, current photosynthesis, and adventitious root formation in Pelargonium cuttings. Plant Sci. 168:1547-1560.

Rapaka, V.K., J.E. Faust, J.M. Dole, and E.S. Runkle. 2007. Diurnal carbohydrate dynamics affect postharvest ethylene responsiveness in portulaca (Portulaca grandiflora 'Yubi Deep Rose') unrooted cuttings. Postharvest Biol. Technol. 44:293-299.

Riov, J. and S.F. Yang. 1982. Effects of exogenous ethylene on ethylene production in citrus leaf tissue. Plant Physiol. 70:136-141.

van Doorn, W.G. 2004. Is petal senescence due to sugar starvation? Plant Physiol. 134:35-42.

Warner, H.L. and A.C. Leopold. 1969. Ethylene evolution from 2-chloroethylphosphonic acid. Plant Physiol. 44:156-158.

Weber, K. and M. Osborn. 1969. The reliability of molecular weight determinations by dodecyl sulfate poly acrylamide gel electrophoresis. J. Biol. Chem. 244:4406-4412.

Woodrow, L., R.G. Thompson, and B. Grodzinski. 1988. Effects of ethylene on photosynthesis and partitioning in tomato, Lycopersicon esculentum. Mill. J. Exp. Bot. 39:667-684.

Woolf, A.B., J. Clemens, and J.A. Plummer. 1995. Leaf maturity and temperature affect the selective removal of floral buds from Camellia with ethephon. J. Amer. Soc. Hort. Sci. 120:614 621.

Yang, S.F. 1969. Ethylene evolution from 2chloroethylphosphonic acid. Plant Physiol. 44:1203-1204. 